\title{
Teachers' Perceptions on Senior High School Readiness of Higher Education Institutions in the Philippines
}

\author{
Imee C. Acosta ${ }^{1, *}$, Alexander S. Acosta ${ }^{2}$ \\ ${ }^{1}$ Department of Fashion \& Graphic Design, Technological University of the Philippines, Philippines \\ ${ }^{2}$ Department of Administration, Technological University of the Philippine, Philippines
}

Copyright $(2016$ by authors, all rights reserved. Authors agree that this article remains permanently open access under the terms of the Creative Commons Attribution License 4.0 International License

\begin{abstract}
The focused of this study is on the readiness of higher education institutions in the Philippines to the implementation of the Senior High School program of the new K-12 curriculum. Data were collected through a survey questionnaire. The findings reveal five predisposing factors, namely: eligibility, staffing guidelines, course streamlining, workforce surplus management, and alternative programs to be determinants of senior high school readiness among college teachers and higher education institutions that will ensure sustainability and the promotion and protection of the welfare of the affected faculty and other employees in the higher education sector.
\end{abstract}

Keywords K-12, Preparedness, Eligibility, Higher Education Institutions, Staffing Guidelines, Course Streamlining, Workforce Surplus Management

\section{Introduction}

In the Philippines, one of the major thrusts of former President Benigno Aquino's government was the enhancement of the basic education program known as the Republic Act No. 10533 series 2012 which was signed into law on May 15, 2013. The law was enacted and promulgated because the Philippines is the last country in Asia and one of only three countries worldwide with a 10 -year pre-university cycle. This recent educational reform efforts instituted by the Philippine government intends to improve the quality of the high school graduates. These new graduates are envisage to become more competitive in the global business arena and to bring more success that would contribute towards building the nation and be at par with the rest of the world.

The implementation of the universal kindergarten began in SY 2011-2012, followed by the new curriculum for Grade 7 in SY 2012-2013. This was primarily aimed to strengthen the Philippine basic education curriculum and increase the number of years of basic education [1,2]. The new program covers Kindergarten plus 12 years of basic education. Under this program a student will be required to undergo kindergarten, six years of elementary, four years of junior high school and two years of Senior High School [3]. The additional two years in senior high school was targeted to prepare students for tertiary education, middle level skills development, entrepreneurship, and global employment [4].

However, the full implementation of the K-12 program will be marked by the entry of the first batch of senior high schools in June 2016. This would mean that there will be no college freshmen for SY 2016-2017 and SY 2017-2018 and no second year enrollees for SY 2017-2018 and SY 2018-2019. While there will already be college freshmen by 2018; there will be no third year college students for SY 2018-2019 and SY 2019-2020, and no fourth year college enrollees for SY 2019-2020 and SY 2020-2021 [5]. Colleges and Universities or the Higher Education Institutions (HEIs) are expecting a drop of enrollment during these five years until SY 2021-2022 when things are expected to normalize [6]. As the new college curriculum starts to roll in SY 2016-2017 most colleges and universities will be affected, not only by the drop of enrollment but also by the reduction of course offering and decrease in faculty workload. The workload of General Education college faculty members will be adversely affected because of the phasing out and/or realignment of courses since some of the college subjects are already transferred and taught in the senior high school [7].

It can be construed from the above scenarios, that no new enrollees and reduction of workload for faculty, would mean loss of income for colleges and universities, decrease in faculty salaries, and possibly, not enough jobs for teachers. Hence, creating a serious threat to the employment of college faculty and staff working in the higher education sector $[2,6,8,9]$. The Higher Education Institutions (HEIs), such as universities and colleges, are viewed as critical partners in implementing the K-12 education policy at the national level. With few months left before the K-12 program is in full swing, HEIs have been making preparations to ensure that their institution is ready for the transition period in 2016 where there will be no freshmen enrollees for two years.

However, because of the growing concern of the 
downsizing impact brought about by the implementation of the new program; this study is geared towards assessing the readiness of Colleges and Universities to bridge the gap brought about by the implementation of the senior high school program. The researcher finds it necessary to determine the required preparations to support the "would-be affected" faculty to serve as implications for alternative program initiatives to mitigate the negative impact of the nationwide implementation of the K-12 program. Constructively, the idea of embracing innovation in education is pressing to effecting change in the educational reform agenda in the Philippines. The successful implementation comes when the teachers and educational institutions decide to adopt; thus, making preparation plans to embrace the new curriculum and be ready to undertake changes to its full implementation are among the challenges to accept realistically.

\subsection{Literature Review}

\subsubsection{Faculty-related Factors}

\section{Length of Service}

One of the downsizing effect of the implementation of the $\mathrm{K}-12$ program is its implication to the employees of the higher education sector; college teachers in particular who expressed concern of displacement, retrenchment, and unemployment $[4,6,10,11]$. However, there is an underlying assumption that job security can be acquired solely through length of service or seniority [12]. Length of service or seniority is a system that is used to designate an employee's status in relation to other employees of the same workplace, to determine matters such as layoff and recall ordering, and the awarding of benefits and promotions [13]. Based on an employee's seniority, preference can be accorded to him or her in such areas as layoff, promotion, transfer, shift assignment, scheduling, vacation accrual, and recall after temporary layoff. Seniority is used as a means of gauging the relative status of one employee with respect to another based on length of service [14]. The practice of seniority has been ingrained in society since the earliest cultures, and seniority-based job security was adopted by the trade union movement from the time of its inception. Although the seniority principle has existed for generations in employment practices such as apprenticeships, it is known that the United States printing trades debated seniority in the 1890 's, while the manufacturing industries began negotiating seniority rights in the 1920's $[14,15]$.

\section{Eligibility}

The current education reform agenda or K-12 program does not only call for academic excellence but also on higher teacher qualification. One of the initiatives to ensure high quality teachers is through the licensing system. Teacher licensure is a key requirement that allows teachers to engage in the teaching profession [16]. Passing the teacher licensure examination is important because this ensures that teachers are well trained before entering the classrooms [17] and it is a defining attribute of a high quality teacher $[18,19]$. In addition, licensed or certified teachers are associated with increased student achievement [20, 21,22]. Therefore, licensure is an important element to assure quality in the teacher workforce [23] because teachers play a pivotal role in advancing learning. Hence, it is important to establish the desired level of teacher competence before the start of practice.

As defined in 1971 by the U.S. Department of Health, Education, and Welfare, licensure is the process by which an agency of government grants permission to persons to engage in a given profession or occupation by certifying that those licensed have attained the minimal degree of competency [24]. In 1834, the State of New York was the first to issue a teaching certificate which paves the way for other states to develop their own specific criteria for state licensure for teachers [25]. In the 20th century education adopted a more professional approach to teacher licensing, giving the profession of education a more prestigious image in terms of a career [26].

Teacher licensure is now used to identify those teacher candidates with the knowledge and skills deemed important for a beginning practitioner and a certified teacher has earned the passage to the profession [23]. The Philippines is also adopting the teacher licensing policy. The country's policy makers and educational leaders have explicitly defined the general requirements to enter the teaching profession; apart from subject matter competence and relevant Master's Degree, a certified professional license is a must which adheres to the Philippine Regulations Commission (PRC) Board of Professional Teachers Act, "except as otherwise allowed under this Act, no person shall practice or offer to practice the teaching profession in the Philippines or be appointed as teacher to any position without having previously obtained a valid certificate of registration and a valid professional license from the Commission" Republic Act 7836, Article IV, Section 27 [27]. Licensure therefore is a function of the state and the policymakers regulates the professions.

It is vital that educators adhere to these standards to meet the required qualifications of those who enter the teaching profession. One great benefit of teaching certification is job security. The teaching profession is more secure than many other fields, especially for certified or professionally licensed teachers [28]. With the start of senior high school, the Department of Education has called on "qualified and highly-competent teachers, professionals, practitioners, and experts" interested in teaching subject areas of the 4 Senior High School tracks: academic, technical-vocational-livelihood, arts and design, and sports [6]. However, it has been stipulated that only applicants with a Professional Regulation Commission (PRC) teaching license "and/or appropriate certification" will be given permanent full-time status. These hiring guidelines under the K-12 implementing rules and regulations are set to ensure that the enhanced basic education program meets the demand 
for quality teachers [27].

\section{Courses Taught}

One of the outlines of RA 10533 is the revision of the Philippine Basic Education curriculum by aligning it with outcomes-based education, the same pedagogy used in K12. The Commission on Higher Education came out with guidelines for the revised General Education Curriculum by reviewing the college curriculum and fine-tuning the courses not just for General Education, but for each specialization to complement the new subjects that will be taught in senior high [29]. As the new curriculum starts to roll in 2018, most colleges and universities will be affected due to the reduction of course offering and decrease in faculty workload since some of the college subjects will be transferred and taught in the senior high school. The workload of General Education college faculty members will be adversely affected because of the phasing out and/or realignment of courses [7].

The implementation of the new K-12 curriculum is causing an on-going distress about what will happen to the college teachers who are teaching General Education (GE) subjects since the first batch of freshmen students will come in 2018. This scenario is raising concern to some college professors due to fear of displacement, retrenchment, and unemployment [9]. To remain employed, GE teachers can apply to become high school teachers or part-time Senior High School teachers while retaining their college posts, if their institution allows. By 2018, there will be freshmen coming in and if they are qualified to teach the new subjects in the revised GE curriculum, GE teachers can return to teaching only college students, while those who are teaching a Specialized or Major Course will retain their positions [30]. The shift to the K-12 program has resulted to various issues and concerns among college teachers particularly those who are teaching the General Education subjects. To ensure that employees are protected, it is up to the school management, particularly of the private higher institutions, of Higher Education Institutions to provide interventions to the would-be affected faculty.

\subsubsection{Preparation Plans}

Preparation is the stage when individual or individuals plan to adopt the new program and undertake change in the immediate future. In this stage, people have considered the rationale, processes, and anticipated outcomes of the reform and made a definite decision to engage in change [31]. The ability to plan for change and coordinate among various participants is also important to the ultimate effectiveness of new endeavors [32]. With the full implementation of the latest educational reform agenda or K-12, some colleges and universities have already prepared for the effective implementation and smooth transition of the program.

\section{Course Streamlining}

The new K-12 program puts a high-value on holistically developed citizen through a combination of education input and curriculum reform [33]. This change in the basic education system has integrated the General Education courses of the higher educaiton program to the senior high school core courses, hence, creating a window for the revision of the current college general education curriculum. The Commission on Higher Education (CHED) is mandated to make sure that the college curriculum is revised to complement the new K12 curriculum.

Under the new General Education curriculum, undergraduate students are exposed to various domains of knowledge and ways of comprehending social and natural realities, developing in the process, intellectual competencies, and civic capacities. The CHED's Memorandum Order number 20, series of 2013 provides the framework and rationale of the revised GE curriculum as a paradigm shift and in the context of the $\mathrm{K}$ to 12 curriculum based on college readiness standards. It sets the goals, outcomes and competencies, revised core courses and electives. It also includes capacity building for start-up and continuing sustainability program. It is a set of minimum standards for the general education component of all the degree programs that applies to private and public Higher Education institutions in the country [34].

This proactive strategy of streamlining or restructuring the curriculum provides a roadmap of planned educational experiences conferred to the learners by their teachers. [35]. Hence, colleges and universities are making adjustments in their curricular programs and course offerings to align with the pedagogies of the K-12 program. Ateneo de Manila University for one has revised their core curriculum as part of their transition plan for K-12. An Ad Hoc Committee was formed from curriculum committee and representatives from different departments to study different options [36]. In like manner, the University of the Philippines also prepares for the widespread influence of the 21 st century education program in order to cushion its anticipated impact. It has unrolled a roadmap in response to its role as the Philippines' only national university, a leader and model in instruction, research and extension work. To affirm UP's leadership role in education, it has embarked on a major change in its teaching pedagogy, quality assurance assessments, and curricular programs, including the review of its General Education curriculum [37].

The curriculum adjustments and course streamlining made by the higher education institutions are indications of support to the country's educational reform agenda that is primarily driven by the effort to address the onslaught of globalization and regional cooperation for the graduates of the Higher Education Institutions to be globally competitive [37]. It also aims to meet the standards of education in the global world where our graduates with only ten years of basic education are disadvantaged [38].

\section{Staffing Guidelines}

During the transition period, the Commission on Higher Education (CHED) is tasked and mandated to implement strategies to protect higher education institutions and their employees from severe losses during the transition. CHED 
shall partner with DepEd, TESDA, PRC, and DOLE to develop contingency plans given that the low number of graduates during the transition period will mean reduced human resources. It should uphold educational institutions and their employees to ensure that "the rights of labor as provided in the Constitution, the Civil Service Rules and Regulations, Labor Code of the Philippines, and existing collective agreements," as well as "the sustainability of the private and public educational institutions, and the promotion and protection of the rights, interests and welfare of teaching and non-teaching personnel" are prioritized [27,29]

Education Secretary Armin Luistro has encouraged the Higher Education Institutions (HEIs) to work together with the Department of Education (DepEd) to mitigate the negative impact of the $\mathrm{K}$ to 12 Program, particularly to faculty members who might be displaced due to the implementation of the Senior High School (SHS) Program. If the college or university plans to offer the Senior High School program, its existing faculty members can teach incoming Grade 11 students given that they undergo re-tooling and training [39]. The Department of Education's hiring needs for SHS include 30,000 teaching staff (full-time and part-time teaching positions) and 6,000 non-teaching staff every year for school years 2016-2017 and 2017-2018. The purpose of this call is to have a preliminary pool. Once the teaching positions are created, schools division offices shall publish vacancies for a period of 10 days in compliance with Republic Act 7041 and priority will be given to the affected and displaced faculty from higher education institutions [6]. This demand for SHS teachers is proposed as mitigation for the faculty lay-offs in higher education institutions [9].

The Department of Education will open a "Green Lane" to prioritize and fast-track their hiring needs, in keeping with RA 10533, and will match them according to locality and salary [29]. However, priority will be based on ranking, while a successful applicant's teaching rank, salary grade, and status of appointment will depend on his/her qualifications. Only applicants with a Professional Regulation Commission teaching license "and/or appropriate certification" will be given permanent full-time status. According to the $\mathrm{K}$ to 12 's implementing rules and regulations, those who have not yet taken the Licensure Examination for Teacher (LET) need to pass the exam within 5 years after they were hired. But taking the LET is not required for educators and practitioners who are willing to teach on part-time basis $[6,40]$.

\section{Workforce Surplus Management}

The labor implications of the K-12 program on college workers is one of the basis of the critics' opposition to the implementation of the program. The latest figures from the Commission on Higher Education showed that 13,634 teaching staff and 11,456 non-teaching staff from higher education institutions may be displaced because of the program $[6,29]$. This is based on the latest data from CHED's survey of higher education institutions and their faculty in November 2014. This also takes into account the latest data from DepEd, wherein 637 higher education institutions will open and operate senior high schools (as of May 31, 2015). This means they will continue to have enrollees and can keep their personnel through the transition period, and may even need to hire more teachers later on.

However, these numbers do not include employees from state universities and colleges (SUCs), because the SUC budgets for the transition years are enough to cover all the people who would otherwise be displaced, nor does it include permanent workers from local universities and colleges (LUCs), because these employees cannot be retrenched during the transition period (except on grounds of incompetence or immorality). It was also taken into account that 25 percent of General Education (GE) subjects are taught in third and fourth years which means that not all faculties who teach GE will be displaced [29].

This is precisely why CHED, DepEd, DOLE, and the Higher Education Institutions have designed responses to provide support to those who may lose their jobs. During the transition period, year 2016-2018, Ateneo has assigned the departments who will reconfigure faculty appointments and assignments to manage the anticipated workloads. Some of the college faculty will be teaching grades 11 and 12 noting the belief that there will be no freshmen applicants during the roll out of Senior High School in 2016 [36,40]. Likewise, Miriam College, one of the few schools in Metro Manila recognized as a $\mathrm{K}$ to 12 model school with a Grade 7 already in place, has set up various committees to ensure the seamlessness of transition across all levels, particularly considering the welfare of the college faculty [41]. The University of the Philippines has crafted its own specific plans and prepares their programs to address the impact of K-12 that ripples to the faculty's academic load, administrative staff functions, fiscal positions, support services and admission processes [37].

\section{Alternative Programs}

The Department of Education (DepEd) is in constant coordination with CHED and DOLE on the actual number of affected faculty from private higher education institutions (HEIs). The worst-case scenario projects that 39,000 HEI faculty will lose their jobs over 5 years but this will only happen if none of the HEIs will put up their own Senior High Schools. However, DepEd is hopeful that the number of affected faculty will be reduced because they are currently processing over 1,000 SHS applications from private institutions [27].

The Commission on Higher Education (CHED) has created a transition plan for college teachers who will be displaced by the introduction of Senior High School in AY 2016-2017 [42]. CHED, for its part, has designed development packages for faculty and staff who will experience a much lower workload during the transition, with the view of not only curbing the adverse effects of the transition but also, and more importantly, upgrading higher 
education in the country. There will be scholarships for graduate studies and professional advancement. CHED will give a total of 15,000 scholarships to higher education personnel for 8,000 to complete master's degrees and another 7,000 to finish doctorate degrees.

There is also a provision of development grants for faculty and staff who may not wish to go on full-time study may still avail of grants that will allow them to retool, engage in research, community service, industry immersion, and other programs throughout the transition period. Innovation grants for institutions are available. Higher education institutions are given the opportunity to apply for innovation grants to fund the upgrading of their programs through: (1) international linkages, (2) linkages with industry, (3) research, or (4) the development of priority, niche, or endangered programs [29].

Likewise, Department of Labor and Employment will provide income support for a maximum duration of one year, employment facilitation that matches their skills to the current job market, and training and livelihood programs in case the affected personnel may want to pursue entrepreneurship. Policies that determine qualifications, requirements, and modes of disbursal for the Development Packages and DOLE's income support are made to ensure that all applicants will adhere to the required standards and procedures. With strategic actions from HEIs, CHED, DepEd, DOLE and other concerned agencies the impact of K-12 implementation will be cushioned [29].

\subsubsection{Readiness}

In the field of education, readiness for reform is often said to be an important predictor of how successfully new policies, programs, or practices will be implemented $[43,44,45]$. If people or groups are ready to embark on the education reform, they are less likely to resist or actively sabotage its implementation; and when they are ready to undertake change, they will do so more energetically and thoughtfully than they might do otherwise [32]. In some perspectives on readiness; to effectively implement a new program, such as enhancing the basic education curriculum, people involved should be given sufficient knowledge of the change in order for them to easily adopt the new program $[46,47,48]$. Readiness is not simply lack of resistance, but instead a more active, engaged willingness, ability, and a transformation of cognition to adopt a new practice [49]. Readiness is thought to be a critical forerunner to successful implementation of the educational reform because the stakeholders are the ones acting on it. When readiness is high, stakeholders are more invested in the change effort, expend greater effort in the change process, and exhibit greater persistence in the face of obstacles or setbacks which contribute to a successful implementation of the new program [44].

Readiness to any changes in the educational system has enduring, situation-specific, and conditional components [50]. It is the extent to which a person or a group is conditioned to accept, embrace, and adopt the reform $[51,52]$.
Some view readiness as an individualistic state, where individuals interact with potential change, develop a stance toward it, and then act accordingly [31,53]. Components of individual readiness might involve self-efficacy, the perception that one will be able to undertake change successfully or fear of the consequences of change $[54,55,56]$. It refers to each stakeholder's shared resolve to implement the new program and shared belief in their collective capability to do so [44]. Eyewitnesses of reform view readiness as an organizational, structural, or collective characteristic [32]. However, some suggest that failure to establish adequate readiness accounts for one-half of all unsuccessful, large-scale reform efforts [57].

Relative to this, it can be surmised that the people are the real source of, and the vehicle for change, because they are the ones who will either embrace it or resist it [58]. Therefore, it is vital to assess individual's readiness perception prior to any change attempt [59]. By assessing readiness for the full implementation of the K-12 program, leaders of the academe, educational managers, educators, and educational development consultants can identify gaps, drawbacks, and problems that may exist. Therefore, assessing the readiness of selected colleges and universities in the Philippines for the implementation of K-12's senior high school program will serve as the impulse for enhanced implementation strategy and craft alternative interventions or measures for any anticipated negative impact. The successful implementation of the K-12 curriculum rests on the willingness and readiness of the education sector and stakeholders to embrace change.

\subsubsection{K-12 Program}

$\mathrm{K}$ to 12 stands for kindergarten plus 12 years of elementary and secondary education. This educational system for basic and secondary education is widely adopted around the world [60]. In 2009, when Barack Obama was newly elected as President of the United States, one of his agenda is a change in education. So, in September 2009, the US created a reform in their K-12 program, as moving forward in the areas of Elementary and Secondary Education Act (ESEA) reauthorization, Race to the Top, and the development of Common Core Standards [61]. The goals for the education reform included encouraging high academic standards, supporting struggling schools, closing the achievement gap, strengthening the pool of educators, reducing the dropout rate and boosting college access [62]. The K-12 reform is an important pipeline in meeting the country's signature goals to regain its former leadership position of boasting the highest postsecondary educational attainment rate in the world [63]. And so the work of reauthorizing ESEA begins in states and districts across America among educators and policy makers, parents and community leaders as the work is as urgent as it is important [62].

Today, in similar manner, the Philippine Educational System is undergoing a major overhaul, which is the resulting development of the Philippine Education for All (EFA) 2015 initiative that serves as the critical legal 
framework for inclusive education which emphasizes the need to provide basic education for all, the children, youths, and adults; and development of enriched basic education with a formal curriculum. To attain the goals of EFA, one of the critical production tasks created is the adoption of a 12-year program of formal basic education by adding two more years to the existing 10-year basic education schooling [64]. The Department of Education (DepEd) Secretary Armin Luistro announced in 2010 the government's priority program to synchronize our educational system with the rest of the world through the Enhanced Basic Education Program or K-12. The reform is strengthened by the findings of the regional comparison study of SEAMEO INNOTECH (2012) which revealed that the Philippines is the only country in Asia, one among only 3 countries worldwide, that requires only 10 years of combined elementary and secondary education prior to entering a university or a college.

The proposal includes implementation of a new curriculum, improvements in teaching quality in order to produce globally competitive graduates, and be at par with the rest of the world. The reform is urgent and important since a college graduate from the Philippines is short of qualifications compared to graduates from other countries. This short period of time spent in school has been said to be the contributing factor for non-recognition of our college graduates and their degrees in the international level [65]. Okabe [33] added that the long-standing system with high school ending at age 15 or 16 has been the cause of many problems both pedagogical and economic, such as congested curricula, non-eligibility to enter overseas tertiary educational institutions, the ineligibility of graduates for immediate employment due to age discrepancy being under the legally employable age, and inadequacy of global standards.

From among various proposals and studies conducted to come up with an enhanced model that is suitable to the Philippine context, DepEd proposed the K-6-4-2 model or the $\mathrm{K}$ to 12 model. This model involves kindergarten, six years of elementary education, four years of junior high school (Grades 7-10), and two years of senior high school (Grades 11-12). The two years of senior high school intend to provide time for students to consolidate acquired academic skills and competencies. The curriculum will allow specializations in science and technology, music and arts, agriculture and fisheries, sports, business and entrepreneurship [60].

Under the new education program, the length of basic education has been expanded by adding two more years to the existing four years of secondary education plus one year of kindergarten; making 13 years of basic education. This extension of basic education brings the country into conformity with other countries worldwide. The educational shift does not only focus on curriculum enhancement but also aims to produce holistically developed citizens equipped with $21^{\text {st }}$ century skills essential for both life-long learning and employment. DepEd is very optimistic that the K-12 program will ease the inadequacies of the Philippine Education System by enhancing the competitiveness of Filipino graduates and restoring the country's competitive edge over other countries in Asia and the world [66].

The enhancement of the basic education curriculum is the flagship education program of the Aquino Administration and Department of Education. The Department seeks to create a basic education sector that is capable of attaining the country's Education for All Objectives and the Millennium Development Goals and President Benigno Aquino's 10-point basic education agenda. These policy reforms are expected to introduce critical changes necessary to further accelerate, broaden, deepen and sustain the Department's effort in improving the quality of basic education [67]. The implementation started in School Year 2012-2013 when the Department of Education (DepEd) implemented the enhanced K to 12 Basic Education Program or Republic Act No. 10533. This was signed into Law in May 15, 2013 that institutionalized the program and enabled the nationwide implementation making $\mathrm{K}-12$ as the legal framework of Philippine basic education system $[1,5]$. The implementation of the Enhanced Basic Education Program or K-12 will pose a positive implication to every Filipino college graduate as they will gain automatic recognition in the international labor arena.

\subsubsection{Senior High School (SHS) Program}

After considering various proposals and studies, the model that is currently being proposed by DepEd is the K-6-4-2 Model. This model involves Kindergarten, six years of elementary education, four years of junior high school (Grades 7 to 10) and two years of senior high school (Grades 11 to 12). The additional two years of senior high school intend to provide time for students to consolidate acquired academic skills and competencies and will equip learners with skills that will better prepare them for the future, whether it be for employment, entrepreneurship, skills development (further Tech-Voc training), and higher education or college. The Senior High School Curriculum was developed in line with the curriculum of the Commission of Higher Education (CHED) to ensure that by the time the students graduate from Senior High School, they will have the standard knowledge, skills, and competencies needed to go to college [27].

The Senior High School (SHS) covers eight (8) learning areas as part of its core curriculum, and adds specific tracks (similar to college courses) based on four (4) disciplines: (1) Academic (which includes Business, Science \& Engineering, Humanities \& Social Science, and a General Academic strand) (2) Technical Vocational Livelihood (with highly specialized subjects with TESDA qualifications) (3) Sports (4) Arts \& Design. The development of tracks based on different competencies and/or student interest is an integral component of the program. These tracks-based competencies are developed to meet the country's varied human capital requirements, and to prepare students for productive endeavor [66]. 
SHS Students may pick a track based on how he or she will want to proceed after high school graduation. However, students first undergo assessments to determine their strengths and interests. These will include an aptitude test, a career assessment exam, and an occupational interest inventory for high schools. Career advocacy activities will also be conducted to help guide students in choosing their specialization or track. Specializations or tracks to be offered will be distributed according to the resources available in the area, the needs and interests of most students, and the opportunities and demands of the community. Existing public and private schools, including colleges, universities and technical institutions may offer Senior High School. There may also be stand-alone Senior High Schools established by DepEd or private organizations. According to law, beginning SY 2016-2017, it is mandatory that students must go through Grades 11 and 12 to graduate from High School [27].

The target of DepEd is to put in place the necessary infrastructure and other necessary arrangements needed to provide Senior High School (SHS) education by SY 2016-2017 when the first batch of senior high schools will start. The nationwide rollout of senior high school impacts those who are working in the higher education sector since students go through two more years of high school instead of going straight to college, resulting in low enrollment in colleges and universities nationwide. This makes the private higher education sector especially vulnerable to loss of revenue, since they depend almost entirely on tuition for salary of their personnel and operating expenses of the schools. Low enrollment means low teaching loads, and low salaries for faculty, resulting in a diminished income, or loss of jobs. CHED has conducted studies that project the anticipated job losses during the transition period, and has partnered with DepEd and DOLE to put programs in place to ensure that personnel in the higher education sector are not only taken care of during the transition, but that this challenge is transformed into an opportunity to upgrade higher education in the country [29].

\subsection{The Research Paradigm}

The graphical representation of the research paradigm of this study shows the possible influence of the faculty-related factors and preparation plans to Senior High School (SHS) readiness.

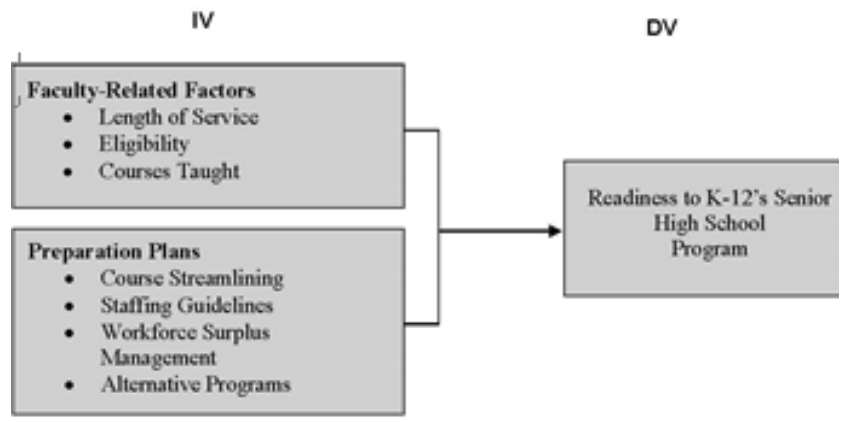

Figure 1. Research Paradigm

\section{Method}

\subsection{The Research Problem}

This study aimed to analyze the determinants of Senior High School readiness of higher education institutions in the Philippines. Specifically, it sought to answer the following questions:

1.) What is the profile of the respondents in terms of:

1.1 Length of Service

1.2 Eligibility

1.3 Courses Taught

2.) What are the preparation plans of the higher education institutions as regards to:

2.1 Course Streamlining

2.2 Staffing Guidelines

2.3 Workforce Management

2.4 Alternative Programs

3.) Do the faculty-related variables significantly influence senior high school readiness?

4.) Do the preparation plan variables significantly determine senior high school readiness among Higher Education Institutions (HEIs) in the Philippines?

\subsection{Population and Sample}

Purposive sampling technique $[68,69,70]$ was utilized. Seventy $(n=70)$ college faculty members from different tertiary level or higher education institutions in the Philippines were purposely chosen to answer the survey questionnaire. The researcher choose the college faculty members as respondents because they are the persons who can provide the needed information by virtue of knowledge and experience $[69,70,71]$. The sampling frame was derived from [72] and [73] that when using multiple regression, a ratio of 10 to 1 is sufficient to provide minimal shrinkage of R2. Having ten observations for each independent variable using six or more predictors in regression equations is a conservative ratio but was reported optimal and appropriate $[74,75,76]$.

\subsection{Research Design}

This study is descriptive in nature using survey approach as its research strategy. It is descriptive because it aims to examine a situation by describing important factors associated with a certain situation, such as demographic, socio-economic, events, behaviors, attitudes, experiences, and knowledge [77]. It describes what actually exists, determine the frequency with which it occurs, categorizes the information [78] and provides a numeric description of trends, attitudes, or opinions of a population by studying a sample of that population [79]. Although, descriptive design is one of the most common forms of research; it is clearly a strong and most appropriate design in this type of study [78]. 
The selection of this research design is based on the research questions and the phenomena being studied.

The survey approach is an attempt to use a systematic set of data typically collected by a questionnaire [80]. The researcher therefore uses information from a sample of individuals to make some inference about the wider population [77]. It involves collecting data in order to answer the research questions by quantifying and describing the variables being measured [81]. Survey approach is typically used under the following conditions: when some degree of generalization is desired, but it is not possible to contact everyone in the population; when time and cost are critical factors; and when the target population is large [80,82]. Hence, this study thus fits the conditions for utilizing survey research approach.

\subsection{Data Collection}

Data were collected through a survey questionnaire. The survey questionnaire was self-created and the survey items were developed based on the analysis of the related literature and other secondary source data, such as news articles and journals $[83,84]$. The survey items include: faculty-related factors along length of service, eligibility, and courses taught; preparation plans along course streamlining, staffing guidelines, workforce surplus management, and alternative programs. The survey questionnaire was composed of closed questions where respondents were asked to choose from a fixed number of options. These are considered to be efficient because data are easy to collect, code and analyze $[85,86]$. Efficiency is important in a survey where researchers attempt to obtain the attitudes or experiences of a representative sample for generalization to a wider population $[77,85]$.

The potential problem with this type of questionnaire is that, this does not allow the respondent the opportunity to give a different response to those suggested [87]. To counter this tendency, the survey questionnaire should be reviewed by a diverse group [86]. A panel of experts including the researcher's local adviser were used to analyze the applicability and usefulness of the content and format of the questionnaire. Extra care was taken to see that all the possible response alternatives are included and that these alternatives do not overlap [86]. Data collection started by obtaining permissions from the Deans or Department Heads through a letter that explained the purpose of the study and requested for voluntary participation in the survey. Following the Deans' or Department Heads' acceptance to participate in the study, the faculty respondents who are going to answer the answer the questionnaire were chosen by the dean or department head.

\subsection{Data Analysis}

Data gathered were analyzed with descriptive and multiple regression statistical techniques using the Statistical Package for the Social Sciences (SPSS) Software V21 x64 to determine the predisposing factors that influence readiness of selected Higher Education Institutions to the implementation of K-12's senior high school program. Faculty-related factors and preparation plans were obtained using percentage and frequency counts. Ranking was utilized to determine which indicators in each of the components of preparation plans have the highest frequency and percentage. The multiple regression analysis was used to test the effect of independent variables on the dependent variable [88] in order to identify how well the faculty-related factors and preparation plan variables influence readiness.

Regression analysis is a form of predictive modelling technique which investigates the relationship between a dependent or target variable and independent variable/s or predictor [89]. A Regression model allows one to test many possible predictor variables at the same time and calculate the relative importance of each variable in the prediction of the target value [88]. It is particularly useful when a researcher wants to control or adjust for differences in many variables [80]. In this study, the nature of regression is linear where the relationship between dependent variable and one or more independent variables is established using a regression line [89].

Prior to the analyses, responses to the independent variables such as eligibility, and courses taught were combined using Transform - Recode command in order to create tables that are easier to read and identify patterns in responses [81]. Similarly, preparation variables were also grouped together using Transform - Compute command due to a very large number of response categories. This is important when using linear regression, but the new data set will typically have all of the original variables with the addition of one or more new variables. The cases of the new data set will be exactly the same as those of the old data $[81,90,91]$. The linear regression analysis yields the values of R (Regression Coefficient), adjusted R-square, and the F-test statistic that would determine whether the model is statistically significant or not. If the model is significant, the individual weights of the components of the model to predict which may have the greatest impact on the dependent variable can be examined [88]. The first proposed model was used to determine the influence of faculty-related variable on senior high school readiness. The second proposed model was used to assess the preparation plan variables to determine readiness

\subsection{Limitations}

Although this study was carefully prepared and has reached its aims, there were some unavoidable limiting factors. First, because of time and money constraints, the study was conducted only on a small size of population of college teachers and might not represent the majority of the higher education institutions in the entire nation. Therefore to generalize the results, the study should have involved more college teachers from different tertiary level institutions nationwide. Second, since the questionnaire was 
designed to limit the faculty-related variables to length of service, eligibility, and courses taught; there might be other variables that are equally important to consider in future studies such as educational attainment or educational qualification, age, employment status, position, etc. For these reasons, the findings of this study cannot be generalized to the broader community based on this study alone.

\section{Results and Discussion}

\subsection{Faculty-related Factors}

Faculty members from selected higher education institutions were the respondents of this study. When grouped according to length of service, $40.0 \%(n=28)$ have served the college and/or university for 2 to 10 years; $37.1 \%$ $(n=26)$ have served for 11 to 20 years; $12.9 \%(n=9)$ have served for 21 to 30 years, $7.1 \%(\mathrm{n}=5)$ have served for 31 to 40 years; and $2.9 \%(\mathrm{n}=2)$ have served the institution for 40 years and above.

As to eligibility, $60.0 \%(\mathrm{n}=42)$ are LET/PBET licensed holders, while $38.6 \%(\mathrm{n}=27)$ hold a Civil Service license and licenses from other fields such as Engineering, Architecture, Accountancy, Nursing, Pharmacy, Laws, etc. and $1.4 \%(n=1)$ does not hold any professional license. Lastly, when grouped according to courses taught, among the 70 respondents, $51.4 \%(n=36)$ are teaching General Education subjects while $48.6 \% \quad(n=34)$ are teaching Specialized or Major Subjects.

Table 1. Faculty-Related Factors

\begin{tabular}{|c|c|c|}
\hline Categories & Freq. & $\%$ \\
\hline Total & 70 & 100.0 \\
\hline Length of Service & & \\
\hline $2-10$ & 28 & 40.0 \\
\hline $11-20$ & 26 & 37.1 \\
\hline $21-30$ & 9 & 12.9 \\
\hline $31-40$ & 5 & 7.1 \\
\hline Above 40 & 2 & 2.9 \\
\hline Eligibility & & \\
\hline LET (Licensure Examination for Teachers) & 42 & 60.0 \\
\hline Other Professional License & 27 & 38.6 \\
\hline None & 1 & 1.4 \\
\hline Courses Taught & & \\
\hline General Education & 36 & 51.4 \\
\hline Specialized/Major & 34 & 48.6 \\
\hline
\end{tabular}

\subsection{Preparation Plans}

Review of college offering ( $\mathrm{n}=60$ or $13.5 \%$ ) is the most chosen indicator pertaining to course streamlining. From this result, it can be gleaned that Higher Education Institutions need to review their college offering to align their programs with the revised college general education curriculum that complements with the pedagogies of the K-12 program [34]. A study of Lauraya, et. al. [7] stated that with the revision of the college curriculum most State Colleges and Universities (SUCs) in Region $\mathrm{V}$ will be affected because of the reduction of course offering and phasing out and/or realignment of courses to match with the K-12 curriculum. With this, there will be a decrease in faculty workload and possibly, more teachers with less workload. Although, some academic units will not be affected due to the offering of electives and specialized courses; the review of college offering with the existing program should be designed and reengineered in line with the new curriculum that warrants a smooth transition to the new educational system.

Table 2. Course Streamlining

\begin{tabular}{|c|c|c|c|}
\hline Course Streamlining & $\mathrm{N}$ & $\%$ & Rank \\
\hline Review of college offering & 60 & $13.5 \%$ & 1 \\
\hline Review of faculty work load & 56 & $12.6 \%$ & 2 \\
\hline Review of general education program & 55 & $12.4 \%$ & 3 \\
\hline Review of curricular programs offered by unit & 46 & $10.4 \%$ & 4 \\
\hline Review of courses taught in majors & 44 & $9.9 \%$ & 5 \\
\hline Review of teaching pedagogy & 41 & $9.2 \%$ & 6 \\
\hline Quality assurance assessment of curricular & 40 & $9.0 \%$ & 7 \\
\hline programs & 37 & $8.3 \%$ & 8 \\
\hline Review of academic calendar & 33 & $7.4 \%$ & 9 \\
\hline Review of credit units & 32 & $7.2 \%$ & 10 \\
\hline Review of admission process & &
\end{tabular}

Upgrading of faculty skills ( $\mathrm{n}=54$ or $11.4 \%$ ) is the most chosen indicator as regards to staffing guidelines which is necessary to make the faculty be aligned with the new K-12 curriculum. Drawing on the current discourse, studies and loud views of the K-12 program, Calderon's [92] study concluded that improving the quality of teachers is vital to meet the goal of K-12 in improving the nation's student achievement. Relative to this, the University of the Philippines is now formulating plans for faculty development opportunities that will upgrade their skills [37]. Likewise, the Catholic Bishops Conference of the Philippines (CBCP) urged the tertiary education administrators to provide opportunities to the instructors and professors to upgrade their skills to be able to handle specialized subjects in the senior high school [93]. It can be 
inferred that Higher Education Institutions (HEIs) should formulate appropriate polices and procedures, and study different options in terms of staffing guidelines, particularly in the enhancement of faculty skills; to provide equal opportunity for development and to ensure the promotion and protection of the rights, interests, and welfare of the college professors.

Table 3. Staffing Guidelines

\begin{tabular}{|c|c|c|c|}
\hline Staffing Guidelines & $\mathrm{N}$ & $\%$ & Rank \\
\hline Upgrading of faculty skills & 54 & $11.4 \%$ & 1 \\
\hline Retooling of teaching faculty & 52 & $10.9 \%$ & 2 \\
\hline Review of faculty credentials & 49 & $10.3 \%$ & 3 \\
\hline $\begin{array}{c}\text { Qualification re-alignment with } \\
\text { courses offered }\end{array}$ & 42 & $8.8 \%$ & 4 \\
\hline Performance assessment review & 41 & $8.6 \%$ & 5 \\
\hline Quality assurance of employees & 37 & $7.8 \%$ & 6 \\
\hline $\begin{array}{c}\text { Review of hiring or recruitment } \\
\text { process }\end{array}$ & 30 & $6.3 \%$ & 7 \\
\hline Community service involvement & 29 & $6.1 \%$ & 8 \\
\hline $\begin{array}{c}\text { Review of employment status } \\
\text { Deployment to senior high school }\end{array}$ & 27 & $5.7 \%$ & 9 \\
\hline Review of faculty years of service & 26 & $5.5 \%$ & 10 \\
\hline $\begin{array}{c}\text { Re-classify faculty to academic } \\
\text { support or administrative positions }\end{array}$ & 24 & $5.1 \%$ & 11 \\
\hline Review of committee assignments & 21 & $4.4 \%$ & 13 \\
\hline Age bracketing of faculty & 17 & $3.6 \%$ & 14 \\
\hline
\end{tabular}

Table 4. Workforce Surplus Management

\begin{tabular}{|c|c|c|c|}
\hline Workforce Surplus Management & $\mathrm{N}$ & $\%$ & Rank \\
\hline Grant research load to deserving faculty & 39 & $20.7 \%$ & 1 \\
\hline Deployment to senior high school & 30 & $16.0 \%$ & 2 \\
\hline $\begin{array}{c}\text { Non-renewal of contracts to part-time and } \\
\text { probationary instructors }\end{array}$ & 26 & $13.8 \%$ & 3 \\
\hline Avail of CHEd's stabilization fund & 20 & $10.6 \%$ & 4 \\
\hline $\begin{array}{c}\text { Re-classify faculty to academic support or } \\
\text { administrative positions }\end{array}$ & 18 & $9.6 \%$ & 5 \\
\hline Offer to teach on part-time basis & 16 & $8.5 \%$ & 6 \\
\hline Offer early retirement package & 15 & $8.0 \%$ & 7 \\
\hline Put excess employees on sabbatical leave & 11 & $5.9 \%$ & 8 \\
\hline Retrenchment program & 5 & $2.7 \%$ & 9 \\
\hline Put them on temporary floating status & 4 & $2.1 \%$ & 10 \\
\hline Mandatory separation program & 4 & $2.1 \%$ & 11 \\
\hline
\end{tabular}

The most relevant preparation plan when it comes to staffing guidelines is grant of research load to deserving faculty ( $\mathrm{n}=39$ or $20.7 \%$ ). This suggests that it is one of the best alternatives to keep the affected faculty in their positions. In fact this is one of the suggestions of the Department of Education (DepEd), Department of Labor and Employment (DOLE), Commission on Higher Education (CHEd), and other concerned agencies to minimize the number of displaced college educators once the senior high school is in full swing in 2016. One of the components of CHED's development package is the grant of scholarships for research work and professional advancement [29]. Cognizant to the strategic actions from higher education institutions and education agencies; the impact of $\mathrm{K}$ to 12 will be mitigated for the effective implementation of the new curriculum.

Table 5. Alternative Programs

\begin{tabular}{|c|c|c|c|}
\hline Alternative Programs & $\mathrm{N}$ & $\%$ & Rank \\
\hline Professional development plans & 43 & $19.3 \%$ & 1 \\
\hline Identify areas for new assignments & 42 & $18.8 \%$ & 2 \\
\hline Retain and retool faculty & 40 & $17.9 \%$ & 3 \\
\hline $\begin{array}{c}\text { Link with other academic institutions for } \\
\text { collaborative teaching }\end{array}$ & 35 & $15.7 \%$ & 4 \\
\hline $\begin{array}{c}\text { Faculty exchange program with other } \\
\text { universities }\end{array}$ & 23 & $10.3 \%$ & 5 \\
\hline $\begin{array}{c}\text { Industry collaboration to offer specialized or } \\
\text { tailored classes }\end{array}$ & 22 & $9.9 \%$ & 6 \\
\hline $\begin{array}{c}\text { Community collaboration to offer community } \\
\text { classes }\end{array}$ & 18 & $8.1 \%$ & 7 \\
\hline
\end{tabular}

Among the alternative programs, professional development plans came out as the most relevant and the most chosen among the respondents $(n=43$ or $19.3 \%$ ). The result implies that college educators are willing to pursue professional development activities to keep their employment during the transition period. Some higher education institutions in the Philippines such as the Ateneo, UP, and Miriam College are preparing various faculty development opportunities to manage the perceived impact to faculty employment [36,37,41]. Likewise, the Commission on Higher Education is giving an opportunity to the affected faculty for professional development in order to upgrade teacher quality in the higher education sector of the country [29]. While the current education reform triggered a serious threat to the employment of college educators, the Commission on Higher Education, higher education institutions, and school administrators are formulating an array of alternative plans to the would-be affected faculty of which the identified alternative programs are some of the options considered.

\subsection{Senior High School Readiness}

Based on the respondents' responses pertaining to senior high school readiness, $74.3 \%$ believed that they are ready for the implementation of K-12's senior high school program; $18.6 \%$ indicated that they are not ready; $2.8 \%$ expressed that they are uncertain and partially ready; and $4.3 \%$ did not give any comment. These results define the college teachers' attitude as to their perception of readiness to the implementation of the senior high school program. These teachers believe that they are ready and prepared because they are equipped with the right qualifications and skills needed for the new program. They are positive that the new program will be successful and effective in achieving its goals. 
Table 6. Senior High School Readiness Responses

\begin{tabular}{|c|c|c|}
\hline $\begin{array}{c}\text { Are you and your institution ready for the } \\
\text { implementation of K-12's Senior High School } \\
\text { program? }\end{array}$ & $\mathrm{N}$ & $\%$ \\
\hline Yes & 52 & $74.3 \%$ \\
\hline No & 13 & $18.6 \%$ \\
\hline Partially & 1 & $1.4 \%$ \\
\hline Uncertain & 1 & $1.4 \%$ \\
\hline No Answer & 3 & $4.3 \%$ \\
\hline Total & 70 & $100 \%$ \\
\hline
\end{tabular}

\subsection{Multiple Regression Analysis of Profile Variables and Readiness}

The influence of the variable eligibility on Senior High School readiness among college faculty is significant, that is $\mathrm{F}=4.147$; $(\mathrm{p}=0.46)$ Eligibility accounts for $5.2 \%$ of the variance on Senior High School readiness, hence 94.8\% could be explained by other factors not mentioned in the study. The beta-coefficient (.263) is significant at .046 level. Therefore, college faculty members who passed the licensure examination for teachers are more prepared and ready for the full implementation of K-12 since their license makes them eligible to teach in the Senior High School program of the $\mathrm{K}-12$ curriculum.

Table 7. Regression of Faculty-Related Factors and Readiness

\begin{tabular}{|c|c|c|c|c|}
\hline \multirow{2}{*}{ IV } & \multicolumn{4}{|c|}{ Regression Coefficient } \\
\cline { 2 - 5 } & $\mathrm{B}$ & Beta & $\mathrm{t}$ value & Sig \\
\hline Constant & 18.238 & & & \\
\hline Eligibility & 5.032 & .263 & 2.036 & .046 \\
\hline
\end{tabular}

Dependent Variable: Readiness

Predictors: (Constant), Eligibility

\begin{tabular}{|c|c|c|}
\hline $\mathrm{R}$ & - & .263 \\
\hline R Square & - & .069 \\
\hline Adjusted R Square & - & .052 \\
\hline F Value for ANOVA & - & 4.147 \\
\hline Significance of F & - & .046 \\
\hline
\end{tabular}

\subsection{Multiple Regression Analysis of Preparation Plans and Readiness}

The influence of the combination of the four independent variables on Senior High School readiness is significant, that is $\mathrm{F}=259.787 ;(\mathrm{p}=.000)$. The four preparation plan variables account for $95.2 \%$ of the variance on Senior High School readiness, hence $4.8 \%$ could be attributed to other factors not mentioned in the study. The beta-coefficients are positive; staffing guidelines (.419), course streamlining (.386), workforce surplus management (.231), and alternative programs (.215) and all are significant at .000 level.
However, among the four significant variables, staffing guidelines has the strongest coefficient. Hence, universities and colleges should formulate appropriate policies and procedures, and study different options in terms of staffing guidelines to provide equal opportunity for employment and to ensure the promotion and protection of the rights, interests, and welfare of all employees in the higher education sector, particularly the "would-be affected" faculty members.

Table 8. Regression of Preparation Plans and Readiness

\begin{tabular}{|c|c|c|c|c|}
\hline \multirow{2}{*}{ IV } & \multicolumn{2}{|c|}{ Regression Coefficient } & & \\
\cline { 2 - 5 } & $\mathrm{B}$ & Beta & $\mathrm{t}$ value & Sig \\
\hline Constant & 9.216 & & & \\
\hline Staffing Guidelines & 1.053 & .419 & 9.982 & .000 \\
\hline Course Streamlining & 1.225 & .386 & 10.406 & .000 \\
\hline $\begin{array}{c}\text { Workforce Surplus } \\
\text { Management }\end{array}$ & 1.088 & .231 & 5.984 & .000 \\
\hline Alternative Programs & 1.110 & .215 & 5.514 & .000 \\
\hline
\end{tabular}

Dependent Variable: Readiness

Predictors: (Constant), Staffing Guidelines, Course Streamlining, Workforce Surplus Management, Alternative Programs

\begin{tabular}{|c|c|c|}
\hline R & - & .976 \\
\hline R Square & - & .952 \\
\hline Adjusted R Square & - & .949 \\
\hline F Value for ANOVA & - & 259.787 \\
\hline Significance of F & - & .000 \\
\hline
\end{tabular}

\section{Conclusions}

In light of the findings of this study, the following conclusions were drawn.

- The survey results put emphasis on eligibility as one of the determinants that contributes to the readiness among faculty members of higher education institutions to the nationwide implementation of K-12's senior high school program. This infers that eligible or licensed college teachers are more advantaged and are likely to secure their jobs even if there will be college enrollment gaps starting SY 2016-2017 until SY 2021-2022, since their professional license or eligibility qualifies them to teach and acquire a full-time permanent status in the Senior High School (SHS) program of the K-12.

- On the preparation plans, while the current education reform triggered a serious threat to the employment of college educators, the Commission on Higher Education, Higher Education Institutions, and school administrators are formulating an array of measures to mitigate the impact to the would-be affected faculty. The identified preparation plan variables considered in this study, namely: staffing guidelines, course streamlining, workforce surplus management, and 
alternative programs would be one of the options for consideration to ensure sustainability and the promotion and protection of the welfare of the affected college faculty and other employees.

- Review of college offering is viewed as the most important indicator as regards to course streamlining. The review of college offering with the existing program should be designed and reengineered in line with the new curriculum that warrants a smooth transition to the new educational system.

- Upgrading of faculty skills is regarded as the most pertinent indicator pertaining to staffing guidelines. Administrators from the higher education sector should provide opportunities to the instructors and professors to upgrade their skills to be able to handle specialized subjects in the senior high school.

- On workforce surplus management, the most relevant preparation plan is grant of research load to deserving faculty. This suggests that granting of research load to deserving faculty is one of the best alternatives to keep the affected faculty in their positions and minimize the number of displaced faculty.

- On alternative programs, professional development plans came out as the most relevant indicator which suggests that college educators are willing to pursue professional development activities to keep their employment during the transition period.

- On Senior High School readiness, majority of the college teachers and higher education institutions are ready and prepared for the full implementation of the $\mathrm{K}-12$ program. They have already identified measures for effective implementation and smooth transition of the program. The strong support gathered from various higher educational institutions imply readiness to adopt to the K-12's senior high school program and ensure a success of the program.

\section{Appendix 1}

\section{:::: Senior High School Readiness Survey}

\section{Directions}

Please complete the following questions to the best of your ability. The researcher is interested to learn about your preparation plans for the Senior High School implementation of the new K-12 curriculum. If there is a question that you cannot answer, please feel free to consult with others in your program to obtain the answer. The information you provide will be very helpful for the completion of this study. Thank you for your participation.

\section{::: Section 1: Personal Profile}

01 Name (Optional)

02 Years of teaching service (Between) $01-10$ years

$11-20$ years

$21-30$ years

$31-40$ years

Other (Please mention)

03 Course/s being taught

(Check as many that apply).

General Education

Specialized Course

Major

Other (Please mention)

04 Eligibility

LET
PBET
Civil Service
Other (Please mention)

\section{:::: Section 2: Readiness}

Please check (

05 Are you ready for K-12 implementation?



06 Are you developing personal preparation plans to mitigate the impact of the K-12 implementation?

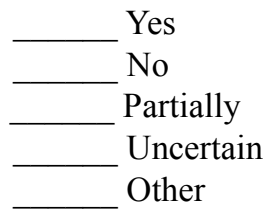

07 Is the college or university ready for K-12?

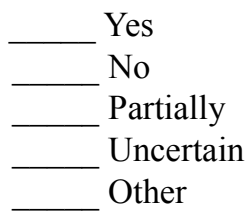

08 Does the college/university create alternative plans for the would-be affected faculty?

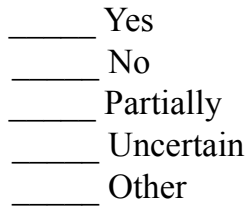


09 Are you and your institution ready for the implementation of K-12's Senior High School program?

Yes
No
Partially
Uncertain
Other

\section{:::: Section 3: Preparation Plans}

10. Which of these large-scale measures below are currently included in your school's preparation plans that could also determine your personal preparation plans?

\section{Check all that apply.}

\section{A. Program/Course Offerings}

Review of GE program

Review of college offerings

Review of credit units

Review of courses taught in majors

Review of academic calendar

Review of curricular programs offered by unit

Quality Assurance assessment of curricular programs

Review of admission process

Review of teaching pedagogy

Review of faculty work load

Other (Please mention)

\section{B. Workforce/Staffing Guidelines}

Review of faculty credentials

Upgrading of faculty skills

Retooling of teaching faculty

Deployment to Senior High School

Re-classify faculty to academic support or administrative positions

Review of employment status

Review of faculty years of service

Age bracketing of faculty

Review of hiring or recruitment process

Performance assessment review

Qualification re-alignment with courses offered

Review of committee assignments

Community service involvement

Quality Assurance assessment of Employees

Other (Please mention)

11. What are the preparations made by the school in terms of possible workforce surplus management that could also determine your personal preparation plans and are favorable to you?

Check all that apply.

Avail of CHED's stabilization fund

Grant of research load to deserving faculty
Put excess employees on sabbatical leave

Put them on temporary floating status

Deployment to Senior HS

Re-classify faculty to academic support or administrative positions

Offer to teach on part-time basis

Offer early retirement package

Mandatory separation program

Retrenchment program

Non-renewal of contracts to part-time and probationary instructors

Other (Please mention)

12. What alternative plans below are currently included in your institutions preparations for the would-be affected faculty and are favorable to you?

Check all that apply.

Identify areas for new assignments

Retain and retool faculty

Professional development plans

Link with other academic institutions for collaborative teaching

Faculty exchange program with other universities.

Community collaboration to offer community classes

Industry collaboration to offer specialized or tailored classes.

Other (Please mention)

\section{REFERENCES}

[1] Cabansag, Marie Grace (2014): Impact Statements on the K-12 Science Program in the Enhanced Basic Education Curriculum in Provincial Schools, Journal of Arts, Science \& Commerce, Vol.- V, Issue-2.

[2] Casiple, Rex (2014). K-12 implementation: Its effect on teaching and non-teaching personnel in school, The Daily Guardian. Available on: http://www.thedailyguardian.net/

[3] Marcelo, Elizabeth (2014). Thousands of professors expected to lose jobs with K-12 implementation, GMA News. Available on: http://www.gmanetwork.com/

[4] Arcangel, Xianne (2014). DepEd to need 81k teachers for senior high school by 2016, GMA News. Available on: http://www.gmanetwork.com/

[5] Lacamiento, Grace Melanie I. (2014). K to 12: The effect on teachers, The Freeman. Available on: http://www.mb.com.ph/

[6] Geronimo, Jee (2014). College professors fear massive retrenchment due to $\mathrm{K}$ to 12 . Available on: http://www.philstar.com/

[7] Lauraya, F.P., Mascariñas, A., Amano, L., Bercasio, R., Cortez, C. Jr., Torres, E. (2013). Bicol SUCS after K-12 and Beyond: An Ex-ante Analysis of the Impact of K-12 Program 
to HEIs, Higher Education Summit 2013 Oriental Hotel, Legazpi City, Philippines

[8] Lacorte, Germelina (2014). More teachers to lose jobs due to K-12 program, Inquirer Mindanao, Available on: http://newsinfo.inquirer.net/

[9] Shahani, L.R. (2015). The challenges of basic education: dealing with K-12. Philstar.com. Available on: http://www.philstar.com/

[10] Tan, K. (2014). Consultations ongoing for 85,000 that will lose jobs due to K-12, GMA News. Available on: http://www.gmanetwork.com/

[11] Flores, H. (2014). DepEd moves to minimize displacement of teachers due to K-12. The Philippine Star. Available on: http://www.philstar.com/

[12] Gibson, Dale (1985). Remedies and Equality. A paper prepared for The National Symposium on Equality Rights.

[13] MacLeod, K. (1987). The seniority principle: is it discriminatory? Queen's University, Industrial Relations Centre, Kingston, Ontario.

[14] US Legal (2010). Seniority, Law \& Legal Definition. Available on: http://definitions.uslegal.com/s/seniority/

[15] Gold, Marc (1985). The Constitutional Dimensions of Promoting Equality in Employment, Equality in Employment, A Royal Commission Report, Research Studies.

[16] Aquino, A. and Balilla, L. (2015). Pre - Service Teachers' Licensure Examination Plans and Content Knowledge. Asia Pacific Journal of Education, Arts and Sciences, Vol. 2 No. 2.

[17] Riney, M. R., et.al. (2006). National Implications: Teacher Education Students' Perceptions of State Licensure Requirements and Pedagogical Training. In National Forum of Teacher Education Journal (Vol. 16, No. 3, pp. 1-7).

[18] Boe, E. E., Shin, S., \& Cook, L. H. (2007). Does teacher preparation matter for beginning teachers in either special or general education? The Journal of Special Education, 41(3), 158-170.

[19] Visco, D. (2015). Determinants of Performance in the Licensure Examination for Teachers (LET) of Abra State Institute of Sciences and Technology. International Journal of Research in Management \& Business Studies. Vol. 2 Issue 1.

[20] Buddin, R., \& Zamarro, G. (2008). Teacher quality, teacher licensure tests, and student achievement. Santa Monica, CA: RAND.

[21] Darling-Hammond, L., Holtzman, D. J., Gatlin, S. J., \& Heilig, J. V. (2005). Does Teacher Preparation Matter? Evidence about Teacher Certification, Teach for America, and Teacher Effectiveness. Education policy analysis archives, 13(42), n42.

[22] Alexander, C., \& Fuller, E. J. (2004, April). Does teacher certification matter? Teacher certification and middle school mathematics achievement in Texas. In annual meeting of the American Educational Research Association. San Diego, CA.

[23] Stand, W. W. (2004). Teacher Quality. An Issue Paper from ETS, Princeton, New Jersey.

[24] Mitchell, K., et.al. (2001). Testing Teacher Candidates: The Role of Licensure Tests in Improving Teacher Quality.
National Research Council. Washington, D.C.

[25] Coggshall, J. (2009). National Comprehensive Center for Teacher Quality. Available on: http://www.tqsource.org/.

[26] Ravitch, D. (2003). Strengthen teacher quality: A brief history of teacher professionalism. White House conference on preparing tomorrow's teachers. Available on: http://www2.ed.gov/

[27] Official Gazette (2013). Implementing Rules and Regulations of the Enhanced Basic Education Act of 2013. Available on: http://www.gov.ph/

[28] PTCA (2014). Benefits of Teaching Certification. Professional Teaching Certification Advice Available on: http://www.teachingcertificationhelp.com/

[29] CHED (2015). Impact on Higher Education: The role of CHED. Available on: http://www.ched.gov.ph/

[30] Cruz, I. (2015). Investing in college teachers, The Philippine Star. Available on: http://www.philstar.com/

[31] Prochaska, J. O., \& Velicer, W. F. (1997). The transtheoretical model of health behavior change. American journal of health promotion, 12(1), 38-48.

[32] Howley, C. (2012). Readiness for Change. White Paper. ICF International (NJ1).

[33] Okabe, M. (2013). Where does Philippine education go? The" $\mathrm{K}$ to 12 " program and reform of Philippine basic education, Institute of Developing Economies Working Paper, Japan.

[34] CHED (2013). CHED Memorandum Order n. 20 s. 2013. Available on: http://www.ched.gov.ph/wp-content/uploads/2013/07/CMONo.20-s2013.pdf

[35] Watermeyer, R. (2011). Curriculum alignment, articulation and the formative development of the learner. Available on: http://www.ibo.org/globalassets/publications/ib-research/cur riculumalignmenteng.pdf

[36] Coronado, A. (2013). Ateneo prepares for K-12. Available on: http:/www.admu.edu.ph/news/

[37] UP System Information Office (2013). UP Gears up for the Impact of the K-12 Curriculum and ASEAN Economic Cooperation 2015 Retrieved January 16, 2015 from http://www.up.edu.ph/

[38] Tabora, Joel (2012). Challenges in Implementing K-12 and Transformative Education, 3rd COCOPEA-Mindanao Congress, General Santos City.

[39] Malipot, Ina H. (2014). K to 12 threatens jobs of 85,000 college workers, Manila Bulletin. Available on: http://www.rappler.com/

[40] Cruz, I. (2013). College teachers in 2016. The Philippine Star. Available on: http://www.philstar.com/

[41] Miriam College (2014). Miriam College is K-12 Ready. Available on: https://www.mc.edu.ph/

[42] Cruz, Isagani (2015). Pros \& Cons in the $\mathrm{K}+12$ Basic Education Debate, The Philippine Star, Available on: 
https://mlephil.wordpress.com/

[43] Fixsen, D. L., Naoom, S. F., Blase, K. A., Friedman, R. M. \& Wallace, F. (2005). Implementation Research: A Synthesis of the Literature. Tampa, FL: University of South Florida, Louis de la Parte Florida Mental Health Institute, the National Implementation Research Network (FMHI Publication \#231).

[44] Weiner, B. J. (2009). A theory of organizational readiness for change. Implement Sci, 4(1), 67.

[45] Weiner, B., Amick, H., \& Lee, S. (2008). Conceptualization and measurement of organizational readiness for change. Medical Care Research \& Review, 65: 4, 379-436.

[46] Adelman, H. S., \& Taylor, L. (2003). On sustainability of project innovations as systemic change. Journal of Educational and Psychological Consultation, 14:1, 1-25.

[47] Rogers, E. M. (1962). Library of Congress Cataloging in Publication Data. Innovation, 11, 2.

[48] Sahin, I. (2006). Detailed review of Rogers' Diffusion of Innovations theory and educational technology-related studies based on Rogers' theory. The Turkish Online Journal of Educational Technology, 5: 2.

[49] Armenakis, A., Harris, S., \& Mossholder, K. (1993). Creating readiness for organizational change. Human Relations, 46: 6, 681-704.

[50] Andreasen, A. R. (1991). Readiness to change: theoretical, empirical and managerial issues. The Consumption of Time and the Timing of Consumption, North-Holland, Amsterdam, 138-148.

[51] Hord, S., et. al. (1987). Taking charge of change. Alexandria VA: Association for Supervision and Curriculum Development.

[52] Cunningham, C., et. al (2002). Readiness for organizational change: A longitudinal study of workplace, psychological and behavioural correlates. Journal of Occupational \& Organizational Psychology, 75:4, 377-392.

[53] Madsen, S. (2008). Preparing faculty and staff for change. Academic Leadership, 6: 1, 2.

[54] Weeks, W., et. al. (2004). Organizational readiness for change, individual fear of change, and sales manager performance: An empirical investigation. Journal of Personal Selling \& Sales Management, 24: 1, 7-17.

[55] Kirch, D. G., et. al. (2005). Reinventing the academic health center. Academic Medicine, 80(11), 980-989.

[56] Susanto, A., (2008). Organizational readiness for change: a case study on change readiness in a manufacturing company in Indonesia. Int.J. Manage. Perspect. 2 (1), 50-62.

[57] Abdel-Ghany, M. M. M. (2014). Readiness for change, change beliefs and resistance to change of extension personnel in the New Valley Governorate about mobile extension. Annals of Agricultural Sciences, 59(2), 297-303.

[58] Philippine Institute for Development Studies (2012). Enhanced K to 12 Basic Education Program: Opportunities and challenges. Volume XII, Issue No. 2. Available on: http://dirp3.pids.gov.ph/

[59] Whilden, Blakely Elizabeth (2011). K-12 Education Reform: Implications and Opportunities for Public Colleges and
Universities. American Association of State Colleges and Universities.

[60] Duncan, Arne (2009). Reauthorization of ESEA: Why We Can't Wait. Secretary Arne Duncan's Remarks at the Monthly Stakeholders Meeting. Available on: http://www.ed.gov/

[61] President Barack Obama (2010), “Address to Joint Session of Congress" (Presidential address, Washington, DC, February 24, 2009). Available on: http://www.politico.com/

[62] UNESCO Report (2014). Philippine Education for All 2015: Implementation and Challenges. Available on: http://planipolis.iiep.unesco.org/

[63] Qatar Day (2016). Qatar equivalency policy may affect 12,000 migrant Filipino engineers, architects. Available on: http://www.qatarday.com/

[64] DepEd (2010). Discussion paper on the enhanced $\mathrm{K}+12$ basic education program. Department of Education. Available on: http://ceap.org.ph/

[65] National Center for Education Statistics (2004). Highlights from the Trends in International Mathematics and Science Study 2003. Available on: http://www.donboscopress.ph/

[66] Calderon, Maria Theresa (2014). A critique of K-12 Philippine Education System. International Journal of Education and Research Vol. 2 No. 10.

[67] Bongcales, Irene (2014). School workers affected by K to 12 face an uncertain future. Philstar.com. Available on: http://www.philstar.com/

[68] Landreneau, K. J., \& Creek, W. (2009). Sampling Strategies. Available on: http://www.natco1.org/

[69] Tongco, M. D. C. (2007). Purposive sampling as a tool for informant selection. Available on: https://scholarspace.manoa.hawaii.edu/

[70] Teddlie, C., \& Yu, F. (2007). Mixed methods sampling a typology with examples. Journal of mixed methods research, 1(1), 77-100.

[71] Bernard, H.R. 2002. Research Methods in Anthropology: Qualitative and quantitative methods. 3rd edition. AltaMira Press, Walnut Creek, CA

[72] Miller, D. E., \& Kunce, J. T. (1973). Prediction and Statistical Overkill Revisited. Measurement and evaluation in guidance, 6(3), 157-163.

[73] Halinski, R. S., \& Feldt, L. S. (1970). The selection of variables in multiple regression analysis. Journal of Educational Measurement, 7(3), 151-157.

[74] Knofczynski, G. T., \& Mundfrom, D. (2007). Sample sizes when using multiple linear regression for prediction. Educational and Psychological Measurement.

[75] Barlett, J. E., Kotrlik, J. W., \& Higgins, C. C. (2001). Organizational research: Determining appropriate sample size in survey research. Information technology, learning, and performance journal, 19(1), 43.

[76] VanVoorhis, C. R. W., \& Morgan, B. L. (2007). Understanding power and rules of thumb for determining sample sizes. Tutorials in Quantitative Methods for Psychology, 3(2), 43-50.

[77] Kelley, K., Clark, B., Brown, V., \& Sitzia, J. (2003). Good practice in the conduct and reporting of survey research. 
International Journal for Quality in Health Care, 15(3), 261-266.

[78] Olsen, C., \& St George, D. M. M. (2004). Cross-sectional study design and data analysis. College Entrance Examination Board.

[79] Creswell, J. W. (2009). Research Design: Qualitative, Quantitative, and Mixed Methods Approaches 3rd Edition. Thousand Oaks, CA: Sage Publications, Inc.

[80] Kirk, Clayton Todd (2003). An Examination Of The Relationship Between Length Of Service, Job Satisfaction, and Propensity To Leave For Faculty At A Texas Community College. Texas Tech University. Unpublished Material.

[81] Babbie, E. (2006). Recoding your data. Sage Publication.

[82] Backstrom, C. H., \& Hursh-Cesar, G. (1981). Survey Research. New York: John Wtley and Sons.

[83] Siniscalco, M. T., \& Auriat, N. (2005). Questionnaire design. Quantitative research methods in educational planning. UNESCO International Institute for Educational Planning, Paris.

[84] Meadows, K. A. (2003). So you want to do research? 5: Questionnaire design. British journal of community nursing, $8,562-570$.

[85] Fink, Kosecoff J (1996). How to conduct surveys. A step by step guide. London: Sage Publications

[86] American Statistical Association (2012). Common Pitfalls in Conducting a Survey. Fairfax County Department of Neighborhood and Community Services. Virginia, USA.

[87] Crawford, I. M. (1990) Marketing Research Centre for Agricultural Marketing Training in Eastern and Southern Africa. Harare Zimbabwe.

[88] De Vaus, D.A. (1986) Surveys in Social Research. Unwin Hyman, London.

[89] Ray, Sunil (2015). 7 Types of Regression Techniques you should know. Analytics Vidhaya. Retrieved from: https://www.analyticsvidhya.com/

[90] Cox, Nicholas J. (2007). Transformation: Introduction. Durham University. Available on: http://fmwww.bc.edu/repec/bocode/t/transint.html

[91] DeCoster, J. (2001). Transforming and restructuring data. Department of Psychology University of Alabama.

[92] Calderon, Maria Theresa (2014). A critique of K-12 Philippine Education System. International Journal of Education and Research Vol. 2 No. 10.

[93] Bongcales, Irene (2014). School workers affected by K to 12 face an uncertain future. Philstar.com. Available on: http://www.philstar.com/ 